\title{
REVITALIZACE EKONOMICKÉ VÝKONNOSTI AUTOMOBILOVÉHO PRŮMYSLU V ČR V PRŮB̌̌HU HOSPODÁŘSKÉ KRIZE SE ZAMĚ̌̌ENÍM NA ÚSTECKÝ KRAJ
}

ECONOMIC PERFORMANCE RESURGENCE OF THE
AUTOMOTIVE INDUSTRY IN THE CZECH REPUBLIC DURING THE
ECONOMIC CRISIS, FOCUSING ON THE USTI REGION

\section{RNDR. VÁClaV NOVÁK, PH.D.}

\section{ING. EVA DRDOVÁ}

\author{
Katedra regionálního a lokálního rozvoje $\mid$ Department Regional and Local Development \\ Fakulta sociálně ekonomická Faculty of Social and Economic Studies \\ Univerzita Jana Evangelisty Purkyně v Ústín. Labem Jan Evangelista Purkyně University in Ústín. Labem \\ $\bowtie$ Pasteurova 1, 40096 Ústí nad Labem, Czech Republic \\ E-mail:vaclav.novak@ujep.cz
}

\begin{abstract}
Anotace
Př́spěvek se zabývá možnostmi využití údajů podnikového účetnictví v regionální analýze. Zkoumána byla ekonomická výkonnost automobilového primmyslu v České republice a v Ústeckém kraji v obdobi hospodářské krize. Využity byly nejdůležitějšsi indikátory, které podnikové účetnictví nabizí, včetně poměrových ukazatelì. Cílem článku je představeni doposud ne přiliš použivané metody k hodnocení postaveni primyslových odvětvi v regionálni ekonomice. Výsledky vlastního šetřeni byly porovnány $s$ veřejně dostupnými statistickými zdroji.

Klíčová slova

ekonomická výkonnost, automobilový průmysl, hospodářská krize, Ústecký kraj

\section{Annotation}

The paper deals with the possibilities of using corporate accounting data in regional analysis. The aim of the study is to analyze economic performance of automotive industry in the Czech Republic and the Usti Region during the economic crisis. There was used the most important indicators from corporate accounting, including financial ratios. This article aims to show not much used methods so far to assess the importance of industries in the regional economy. Own research results were compared with the sources of official statistics.
\end{abstract}

\section{Key words}

economic performance, automotive industry, economic crisis, the Usti Region

JEL classification: R11

\section{Úvod}

Problematikou regionálních disparit se v ČR zabývají nejen regionální ekonomové, ale také odborníci z jiných oborů, např. sociální geografie, sociologie, demografie apod. Jak uvádí Viturka (2010), disparity patří nyní k nejvíce frekventovaným pojmům ve spojení s problematikou regionální politiky 
a regionálního rozvoje. Popsané postupy mohou být dle názoru autora př́spěvku aplikovány prakticky na poli strategického plánování na centrální či regionální úrovni.

Studium ekonomické výkonnosti firem patřilo doposud téměř výhradně do sféry zájmu podnikových ekonomů. Ekonomická literatura (napřr. Kislingerová 2001 nebo Blaha s Jindřichovskou 2006) se však výhradně zabývá měřením ekonomické výkonnosti jednoho podnikatelského subjektu. Uživateli těchto výstupů jsou především majitelé firem, manažeři či auditoři, kteří potřebují znát, jakou hodnotu má konkrétní společnost.

Již od druhé poloviny devadesátých let se tématem finančních analýz odvětví průmyslu začaly zabývat soukromé společnosti v oblasti ekonomického poradenství. Na trhu je dnes dokonce dostupná placená databáze firem obsahující údaje z účetních závěrek společností. Z univerzitních pracoviště se regionálními analýzami založenými na údajích podnikového účetnictví začalo po roce 2000 zabývat Centrum pro regionální rozvoj Masarykovy univerzity v Brně (Kunc, Novák a Řeřicha 2003). O analýzy hodnotící detailně výkonnost průmyslových odvětví na regionální úrovni začaly projevovat zájem také orgány regionální samosprávy. A tak vznikla časově souvislá řada analýz pro Kraj Vysočina (např. Konečný, Osman 2008).

Také Český statistický úřad a Ministerstvo průmyslu a obchodu ČR rovněž vydávají publikace zaměřené na hodnocení průmyslových odvětví prostřednictvím účetních dat (ČSÚ 2012, MPO ČR 2012). Tyto výstupy ovšem obsahují údaje pouze za celou ČR.

V současnosti se zpracováním regionálních finančních analýz průmyslových odvětví v ČR v souvislosti s regionálním trhem práce zabývá Výzkumné centrum konkurenceschopného a udržitelného rozvoje regionů při Univerzitě J. E. Purkyně v Ústí nad Labem (VYCERRO). Tento článek vychází ze systematicky tvořené databáze průmyslových firem ČR a navazuje na již publikované výstupy zaměřené na průmysl (Koutský 2011) a kvalitu zahraničních investic v Ústeckém kraji (Hlaváček 2009).

Cílem příspěvku je pomocí poměrových finančních ukazatelů zjistit, do jaké míry se shodují výstupy z ČSÚ s výsledky vlastního šetření založeného na údajích př́ímo z účetních závěrek. Metoda byla aplikována na jedno průmyslové odvětví, přičemž údaje za jednotlivé subjekty byly agregovány. Vzhledem k tomu, že ČSÚ vychází částečně ze statistických výkazů, které rozesílá jednotlivým zpravodajským jednotkám a částečně ze statistických dopočtů, lze předpokládat, že se oba výstupy budou lišit.

Článek dále představuje regionální pohled na jedno ze stěžejních průmyslových odvětví v období hospodářské krize. Cílem je zhodnotit postavení Ústeckého kraje v rámci automobilového průmyslu ČrR.

\section{1. Účetní závěrky jako zdroj dat}

Účetní závěrky jsou sestavovány v souladu s obecně uznávanými účetními zásadami a standardy. Dodržováním těchto principů je zaručena vzájemná porovnatelnost a kontrolovatelnost finančního účetnictví různých subjektů. V České republice jsou obecné účetní zásady právně kodifikovány (Sedláček, 2005).

Účetní závěrky jsou dle české legislativy povinny sestavovat právnické osoby se sídlem na území ČR a fyzické osoby, které jsou jako podnikatelé zapsány v obchodním rejstř́íku. Podle Obchodního zákoníku z roku 1991 i Velké novely Obchodního zákoníku z roku 2000 jsou účetní závěrky firem př́stupné veřejnosti na krajských soudech a vinternetové verzi Sbírky listin, která je součástí obchodního rejstríku.

Účetní závěrku dle zákona tvoří následující výkazy:

- rozvaha (bilance), 
- výkaz zisku a ztráty,

- prŕloha, která vysvětluje a doplňuje informace obsažené v rozvaze a výkazu zisku a ztráty.

Účetní závěrky nabízí celou řadu údajů o dané firmě. Podávají informace o jejím majetku, závazcích, vlastním kapitálu a dále také o nákladech a výnosech firmy v průběhu účetního období, které zpravidla tvoři 12 měsíců a nemusí být shodné s kalendářním rokem. K základním sledovaným ukazatelům z výkazu zisku a ztráty patří výkony, výkonová spotřeba, účetní přidaná hodnota, osobní a mzdové náklady, výsledek hospodaření. Rozvaha nabízí finanční vyjádření aktiv (pasiv) podniků. Pro zjištění míry zadlužení firmy nabízí rozvaha informaci o cizích zdrojích v bilanci firmy. Př́iloha účetní závěrky obsahuje údaj o průměrném přepočteném počtu zaměstnanců firmy za účetní období.

Jednotlivé absolutní hodnoty proměnných, jež poskytuje účetnictví, jsou dávány do vzájemných relací, přičemž tak jsou vytvářeny tzv. poměrové ukazatele (Neumaierová, Neumaier 2002). Poměrový ukazatel charakterizuje vzájemný vztah mezi dvěma položkami účetních výkazů pomocí jejich poměrů. Používání poměrových ukazatelů stejně jako vztahování údajů z výkazů zisku a ztráty na počet zaměstnanců je pro identifikaci regionálních rozdílů na základě agregovaných dat podnikového účetnictví stěžejní.

Vlastní šetření je založeno na sestavení databáze firem, u nichž byly zjišt'ovány údaje z účetních závěrek. Vzhledem k časové náročnosti pořizování dat bylo rozhodnuto, že údaje budou kompletovány za subjekty s počtem zaměstnanců 100 a vyšším. Vzhledem $\mathrm{k}$ tomu, že řada firem neplní svoji zákonnou povinnost a do Sbírky listin nezasílá své účetní závěrky, nebylo sice možné sestavit kompletní databázi průmyslových podniků, nicméně reprezentativnost šetřeného souboru činí 85 \%. Do analýzy vstupovalo 207 firem, údaje byly zjištěny za 176 subjekti̊.

\section{Hodnocení výkonnosti automobilového průmyslu v období hospodářské krize na základě analýzy dat ČSÚ a vlastního šetření}

Prvním poměrovým ukazatelem, který byl pro komparaci vybrán, jsou agregované údaje o tržbách $\mathrm{v}$ přepočtu na celkový počet zaměstnanců $\mathrm{v}$ automobilovém průmyslu ČR (sekce 29 dle klasifikace CZ-NACE). Z obrázku č. 1 je zřejmé, že hodnoty za automobilový průmysl převyšují průměr celého zpracovatelského průmyslu, což však nic neř́ká o produktivitě či ziskovosti daného odvětví. Dủležitější je rozdílná dynamika přechodu od propadu ukazatele, který charakterizuje objem výroby, $\mathrm{k}$ růstu. Ta byla $\mathrm{v}$ př́ípadě automobilového průmyslu zcela zřetelnější a obrat na rozdíl od zpracovatelského průmyslu jako celku nastal již v roce 2009. To lze zčásti přisuzovat akcím typu „šrotovné“, které aplikovala řada vlád států EU.

Hodnoty ukazatele za automobilový průmysl jsou o něco vyšší v př́ípadě vlastního šetření. To je do značné míry způsobeno tím, že šetřením byly zjištovány výkony celkem. V rámci výkonů průmyslových společností tvoří sice tržby za prodej vlastních výrobků a služeb rozhodující podíl, nicméně řada z nich si účetní bilanci vylepšuje marží, která plyne z nákupu a následného prodeje zboží. Nicméně přes metodicky mírně odlišný přístup bylo možné učinit obdobné závěry jak prostřednictvím údajů ČSÚ, tak díky datům z vlastního šetření.

Ukazatel, který je výsledkem poměru přidané hodnoty a počtu zaměstnanců, je jedním z nejdůležitějších poměrových indikátorů, nebot' jeho prostř̌ednictví získáme velmi cennou informaci o produktivitě společnosti, resp. odvětví. Tento poměrový ukazatel udává v Kč, kolik dané firmě (odvětví) průměrně přináší jeden zaměstnanec ještě před tím, než je zaplacen a než se do účetnictví zakomponují další výnosy a náklady. Neboli kolik Kč z tržeb za prodej vlastních výrobků a služeb a z obchodní činnosti připadá na jednoho pracovníka firmy po odečtení výrobních nákladů (materiál, energie, služby).

Dle obr. č. 2 je zřejmé, že produktivita automobilového průmyslu je daleko vyšší než v celém zpracovatelském průmyslu. Stejně jako v př́ípadě tržeb za prodej vlastních výrobků a služeb byla 
účetní přidaná hodnota na zaměstnance zjištěna u vlastního průzkumu vyšší. To lze odůvodnit faktem, že do vlastního šetření vstupovaly pouze velké a středně velké firmy, kdežto do statistického výkaznictví ČSÚ byly zahrnuty i menší jednotky, které generují nižší hodnoty sledovaného ukazatele. Poněkud překvapivé a hưře odůvodnitelné je zjištění, že produktivita práce v př́ípadě vlastního šetření klesala dva roky po sobě (2008 a 2009). Avšak z dat ČSÚ plyne, že obrat nastal již v roce 2009. Zjištěný nesoulad může být dán za vinu míře statistických dopočtů, které Čsú provádí za zpravodajské jednotky, od nichž nezískal statistický výkaz.

Obr. 1: Tržby za prodej vlastních výrobků a služeb ve zpracovatelském průmyslu ČR a automobilovém průmyslu ČR v letech 2007 - 2010

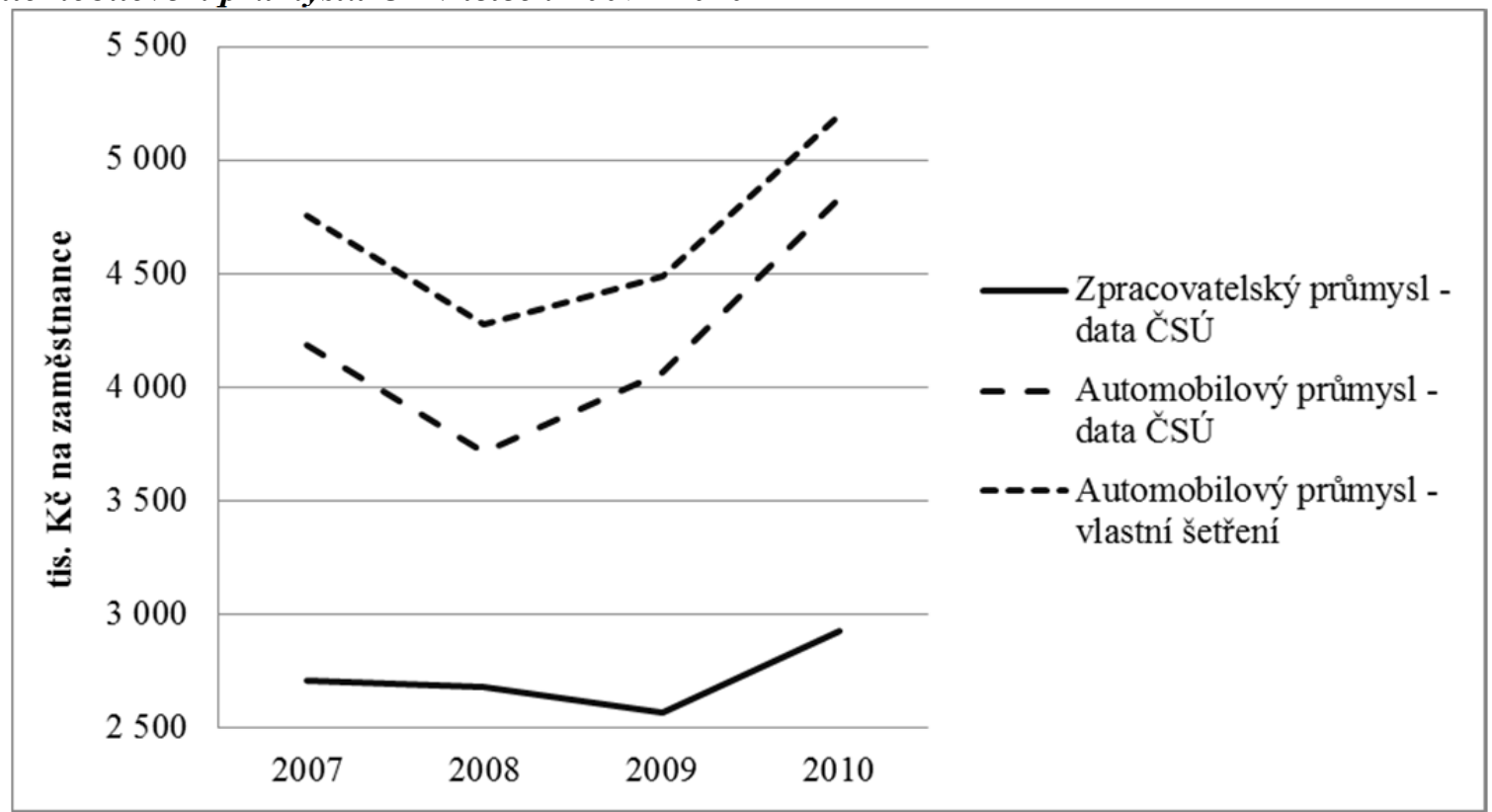

Zdroj: Panorama zpracovatelského průmyslu ČR. Ministerstvo pri̊myslu a obchodu ČR 2011, Praha, 2012; vlastní šetreni

Poznámka: V rámci vlastního šetření byly sledovány výkony. U průmyslových firem tvoří tržby za prodej vlastních výrobků a služeb zpravidla rozhodující podíl na výkonech.

Obr. 2: Účetní přidaná hodnota ve zpracovatelském průmyslu ČR a automobilovém průmyslu ČR v letech 2007 - 2010.

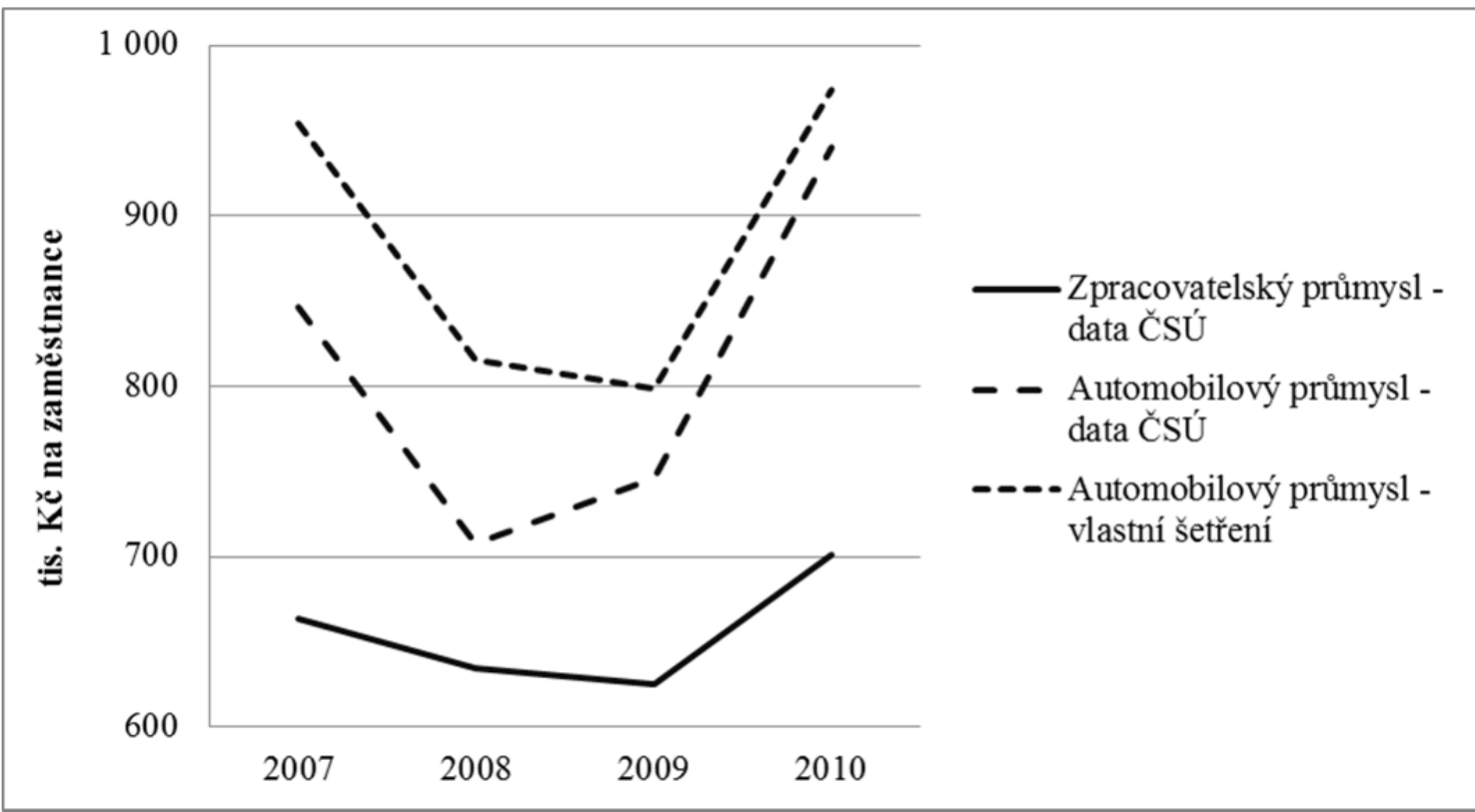

Zdroj: Panorama zpracovatelského průmyslu ČR. Ministerstvo průmyslu a obchodu ČR 2011, Praha, 2012; 


\section{Ekonomická výkonnost automobilového průmyslu v Ústeckém kraji}

Z tabulky č. 1 vyplývá, že hodnota účetní přidané hodnoty na zaměstnance $\mathrm{v}$ automobilovém průmyslu Ústeckého kraje byla po celé sledované období pod úrovní celorepublikového průměru. Nejvíce se údaj za kraj blížil republikové hodnotě v roce 2007, tedy ještě v předkrizovém období. Na druhou stranu po propadu účetní přidané hodnoty na zaměstnance v roce 2008 vykázal automobilový průmysl v Ústeckém kraji růst produktivity práce již v roce 2009. Automobilový průmysl celé ČR zaznamenal nejnižší hodnoty v roce 2009, ovšem nárůst v roce 2010 byl tak razantní, že účetní přidaná hodnota na zaměstnance $\mathrm{v}$ posledním sledovaném roce byla ještě vyšší než v roce 2007. Lze tedy konstatovat, že se dodavatelé komponent pro automobilový průmysl v Ústeckém kraji celkově prezentují nižší přidanou hodnotou své produkce a že zatímco celé odvětví vyšlo v ČR z krizového období (roky 2008 a 2009) významně posíleno, produktivita práce v automobilovém průmyslu v Ústeckém kraji vzrostla jen velmi málo.

Tab. 1: Účetní přidaná hodnota na zaměstnance v automobilovém průmyslu v Ústeckém kraji a v $\breve{C} R$ v letech $2007-2010$ (v tis. Kč)

\begin{tabular}{|c|r|r|r|}
\hline \multirow{2}{*}{ Rok } & \multicolumn{2}{|c|}{ Účetní přidaná hodnota na zaměstnance } & \multirow{2}{*}{ Index kraj / ČR * $\mathbf{1 0 0}$} \\
\cline { 2 - 3 } & Ústecký kraj & ČR & 78,5 \\
\hline 2007 & 749 & 954 & 68,0 \\
\hline 2008 & 555 & 816 & 71,6 \\
\hline 2009 & 572 & 799 & 62,6 \\
\hline 2010 & 610 & 974 & Zdroj: Vlastní šetření \\
\hline
\end{tabular}

Tabulka č. 2 dokumentuje, že o něco dynamičtější a hlavně pro Ústecký kraj méně příznivý vývoj než v prŕpadě produktivity práce byl zaznamenán u ziskovosti automobilového průmyslu. Pokles hospodářského výsledku na zaměstnance celého automobilového průmyslu ČR mezi lety 2007 a 2009 činil $70 \%$. Růst ziskovosti v následujícím roce činil jen $46 \%$, což znamená, že hospodářská krize, přestože výrazně přispěla $\mathrm{k}$ růstu produktivity práce, zapříčinila $\mathrm{i}$ to, že pro firmy automobilového průmyslu je v současnosti podstatně složitější vytvářet zisk ve srovnání s obdobím konjunktury. Ještě komplikovanější může být situace na regionální úrovni, kdy konkrétně v př́ípadě Ústeckého kraje se sledovanému odvětví ani v roce 2010 nepodařilo vymanit se ze ztráty. Lze tedy konstatovat, že se automobilový průmysl Ústeckého kraje, který se vyznačuje na pracovní sílu méně náročnou výrobou, ještě v roce 2010 zdaleka nevypořádal s následky hospodářského poklesu, jehož počátek je kladen do roku 2008.

Tab. 2: Hospodářský výsledek na zaměstnance v automobilovém průmyslu v Ústeckém kraji a v ČR v letech $2007-2010$ (v tis. Kč)

\begin{tabular}{|c|r|r|}
\hline \multirow{2}{*}{ Rok } & \multicolumn{3}{|c|}{ Hospodářský výsledek na zaměstnance } \\
\cline { 2 - 4 } & \multicolumn{1}{|c|}{ Ústecký kraj } & \multicolumn{1}{c|}{ ČR } \\
\hline 2007 & 171 & 254 \\
\hline 2008 & -156 & 102 \\
\hline 2009 & -49 & 77 \\
\hline 2010 & -35 & 194 \\
\hline
\end{tabular}

\section{Závěr}

Komparace dat ČSÚ s údaji z vlastního šetření, založeném na sběru dat z účetních závěrek firem, potvrdila rozdíly hodnot poměrových ukazatelů za automobilový průmysl v období krize. Nicméně lze konstatovat, že v článku prezentovaná metoda hodnocení výkonnosti průmyslových odvětví může být oprávněná. S její pomocí lze hodnotit ekonomickou výkonnost průmyslových odvětví na nižší než republikové úrovni, což dnes neumožňuje žádný veřejně dostupný statistický zdroj. 
Analýza prokázala, že automobilový průmysl v ČR má dle sledovaných poměrových ukazatelů vyšší ekonomickou výkonnost než zpracovatelský průmysl celkem. Také oživení bylo po hospodářském propadu v roce 2008 u tohoto odvětví dynamičtější a částečně k němu došlo už v roce 2009. Dodavatelé komponent pro automobily působící v Ústeckém kraji se v celkovém hodnocení ještě nedokázali vypořádat $\mathrm{s}$ důsledky hospodářské krize, přičemž vykazují podstatně nižší úroveň produktivity práce ve srovnání s průměrnými údaji automobilového průmyslu ČR. Nároky na kvalifikovanou pracovní sílu jsou zde tedy pravděpodobně podstatně nižší, což může být např́íklad důsledkem nevhodně nastaveného systému regionálního školství.

\section{Literatura}

[1] BLAHA, Z. S., JINDŘICHOVSKÁ, I. Jak posoudit finanční zdraví firmy. 3. vyd., Management Press, s. r. o., Praha, 2006. 194 s. ISBN 80-7261-145-3

[2] Český statistický úřad. Ekonomické výsledky průmyslu ČR 2010. Praha, 2012.

[3] HLAVÁČEK, P. The Foreign Direct investments in the Ústí Region: Theory, Actors and Space Differentiation. E+M Ekonomie a Management, 2009, vol.12, iss. 4, pp. 27-39, ISSN 1212-3609.

[4] KISLINGEROVÁ, E. Oceňování podniku. 2. vydání, C. H. Beck, Praha, 2001. 367 s. ISBN 80-7179-529-1

[5] KONEČNÝ, O., OSMAN, R. Hospodařeni průmyslových podniků se sidlem v kraji Vysočina $v$ roce 2006 . Vysočina, Jihlava, 2008, $71 \mathrm{~s}$.

[6] KOUTSKÝ, J. Staré prümyslové regiony - vývojové tendence, možnosti rozvoje. Ústí nad Labem: Univerzita J. E Purkyně, 2011. $125 \mathrm{~s}$.

[7] KUNC, J., NOVÁK, V., ŘEǨICHA, R. Hospodaření průmyslových podniků se sídlem v Brně v roce 2001. In Geografické aspekty středoevropského prostoru. 1. vyd. Brno: Masarykova univerzita, 2003. s. 186 - 190. ISBN 80-210-3208-1

[8] Ministerstvo průmyslu a obchodu ČR. Panorama zpracovatelského průmyslu ČR 2011. Praha, 2012.

[9] NEUMAIEROVÁ, I., NEUMAIER, I. Výkonnost a tržni hodnota firmy. GRADA Publishing, Praha, 2002, 216 s.

[10] SEDLÁČEK, J. a kol. Základy finančního účetnictví. 1. vyd., Praha: Ekopress, s.r.o., 2005. 331 s. ISBN 80-86119-95-5

[11] VITURKA, M. Regionálni disparity a jejich hodnocení v kontextu regionálni politiky. Geografie, 2010. Vol. 115, No. 2, pp. 131-143.

Př́spěvek byl zpracován na základě podpory studentského grantového projektu v rámci specifického vysokoškolského výzkumu na Univerzitě Jana Evangelisty Purkyně v Ústí nad Labem. 